\title{
Amitriptyline in migraine prophylaxis \\ Changes in pattern of attacks during a controlled clinical trial
}

\author{
JAMES D. GOMERSALL AND ALICE STUART
}

From the Departments of Mental Health and Social Medicine, University of Aberdeen, Aberdeen

\begin{abstract}
SUMMARY A double-blind controlled clinical trial of crossover design was conducted in 26 volunteers suffering from migraine. Of 20 subjects who completed the trial, 16 had fewer attacks on amitriptyline than on placebo. Amitriptyline was found to have the greatest effect in reducing attacks with a short warning and in which no specific cause could be recognized. It had least effect in attacks with a long warning and recognized as due to fatigue. The drug was effective only in reducing those attacks with shorter duration and its effect was irrespective of severity. A dosage of between 10 and $60 \mathrm{mg}$, usually taken at night, was found to be adequate.
\end{abstract}

Amitriptyline has been found effective in chronic tension headache (Lance and Curran, 1964) and its beneficial use in migraine has been reported (Friedman, 1968; Mahloudji, 1969).

Although its precise mode of action in migraine is uncertain, amitriptyline and the tricyclic antidepressants possess similarities in structure and pharmacological effect to some of the recently introduced prophylactic agents used in this condition.

\section{SELECTION OF SUBJECTS}

Volunteers were requested via the British Migraine Association and the press. The criteria of migraine used was the presence of intermittent headache with at least three of the following features: unilateral distribution, sensory prodromata, associated nausea; photophobia and throbbing.

All subjects were asked to keep a record of their migraine attacks. These showed the information listed in Table 1 . The charts were returned and discussed every two months with a statement as to their accuracy. It was indicated that attacks causing no disturbance of daily routine should be recorded as mild; those causing some lack of efficiency as moderate, and those causing complete disruption of usual activities should be recorded as severe.

Of 114 volunteers, 94 were excluded as follows. Seventy-five were excluded before or during a 26 week control period. Only those subjects having more than two attacks per month and with over $50 \%$ described as at least of moderate severity were
TABLE 1

DATA RECORDED BY SUBJECTS

\begin{tabular}{|c|c|}
\hline Feature & Aspects noted \\
\hline Warning & $\begin{array}{l}\text { Time of onset, cessation, and charac } \\
\text { teristics }\end{array}$ \\
\hline Time of onset of attack & Timed to nearest hour \\
\hline Time of cessation & $\begin{array}{l}\text { Timed to nearest hour. Hour of } \\
\text { wakening recorded if ceasing durin } \\
\text { the night }\end{array}$ \\
\hline Characteristics of the pain & Situation, type \\
\hline Associated features & $\begin{array}{l}\text { Free description allowed, but classifie } \\
\text { as nausea, photophobia, depression }\end{array}$ \\
\hline Any recognizable cause & $\begin{array}{l}\text { Free description allowed but classified } \\
\text { into: none, weather, psychological, } \\
\text { food or drink, menstruation, fatigue }\end{array}$ \\
\hline Severity & $\begin{array}{l}\text { A subjective estimate on a three point } \\
\text { scale of mild, moderate, and severe }\end{array}$ \\
\hline
\end{tabular}

considered for the trial. Of the 39 subjects satisfying these criteria, 13 were randomly allocated for a study of psychotherapy, and six were withdrawn during the trial (Table 2). On three occasions during the trial, it was necessary to ask for an estimate of an attack from memory owing to failure to record. Cooperation of subjects was excellent.

Blood pressure was recorded initially and at all subsequent visits. The nature of the trial was explained and permission of the patient and his general practitioner obtained. Characteristics of the 20 subjects who completed the trial are shown in Table 3. The types of migraine recognized are those advised by the Ad Hoc Committee of the National Institute for Nervous Disease and Blindness (1962). 
TABLE 2

REASONS FOR EXCLUSION OF 94 SUBJECTS OUT OF TOTAL OF 114 VOLUNTEERS

\begin{tabular}{|c|c|c|c|c|}
\hline $\begin{array}{l}\text { Reason for } \\
\text { exclusion }\end{array}$ & $\begin{array}{c}\text { Exclusion } \\
\text { before } \\
\text { control } \\
\text { period }\end{array}$ & $\begin{array}{c}\text { Exclusion } \\
\text { during } \\
\text { control } \\
\text { period }\end{array}$ & $\begin{array}{c}\text { Exclusion } \\
\text { during } \\
\text { trial }\end{array}$ & Total \\
\hline $\begin{array}{l}\text { Failure to satisfy } \\
\text { criteria of migraine }\end{array}$ & 8 & 1 & -- & 9 \\
\hline $\begin{array}{l}\text { Unwilling to participate } \\
\text { in trial } \\
\text { Under antidepressant }\end{array}$ & - & - & 1 & 1 \\
\hline treatment & - & 一 & 1 & 1 \\
\hline Living at a distance & 23 & 1 & - & 24 \\
\hline Pregnancy & & - & 1 & 1 \\
\hline $\begin{array}{l}\text { Failure to record } \\
\text { attacks }\end{array}$ & - & 7 & 2 & 9 \\
\hline $\begin{array}{l}\text { Allocated for trial of } \\
\text { psychotherapy }\end{array}$ & 一 & 一 & 13 & 13 \\
\hline $\begin{array}{l}\text { Attacks of insufficient } \\
\text { severity }\end{array}$ & - & 35 & - & 35 \\
\hline Side-effects of drugs & - & - & 1 & 1 \\
\hline Total & 31 & 44 & 19 & 94 \\
\hline
\end{tabular}

Total volunteers 114 Subjects remaining after exclusions 20 .

\section{METHOD}

Each subject received tablets of amitriptyline and placebo in random order for periods of 27 weeks each. Attacks occurring during the first week on each tablet were disregarded in order to counteract any lag in the effect of treatment.

No other form of long-term medication was permitted during the trial except contraceptive tablets, which, it was requested, should not be changed. Ergotamine or other usual medication continued to be taken at the time of attacks, but again no changes were made in the form of this therapy during the trial period (Table 4).

Subjects were warned of likely side-effects and these occurred with both preparations (Table 5). Instructions were given to commence with three tablets daily and increase to six if no therapeutic

TABLE 4

MEDICATION TAKEN DURING MIGRAINE ATTACKS

\begin{tabular}{|c|c|c|c|}
\hline \multicolumn{4}{|c|}{ Medication during attack } \\
\hline $\begin{array}{c}\text { None } \\
(\text { no. })(\%)\end{array}$ & $\begin{array}{c}\text { Ergotamine } \\
\text { preparations } \\
(\text { no. })(\%)\end{array}$ & $\begin{array}{c}\text { Simple } \\
\text { analgesics } \\
(\text { no. })(\%)\end{array}$ & $\begin{array}{c}\text { Trifluoperazine } \\
\text { (no.) }(\%)\end{array}$ \\
\hline 210 & 1155 & 630 & 15 \\
\hline
\end{tabular}

effect was observed after two weeks. If undesirable side-effects occurred, however, it was advised firstly that the dose be taken at night, and if the effects still persisted, then a reduction of dosage was made. Patients were reviewed after two and four weeks on each medication, during which time the optimum dose was established and maintained for the last 23 weeks on each tablet (Tablet 6).

Differences were tested for significance using chisquared.

\section{RESULTS}

Sixteen out of 20 subjects had fewer attacks when

TABLE 3

CHARACTERISTICS OF 20 SUBJECTS WHO COMPLETED TRIAL

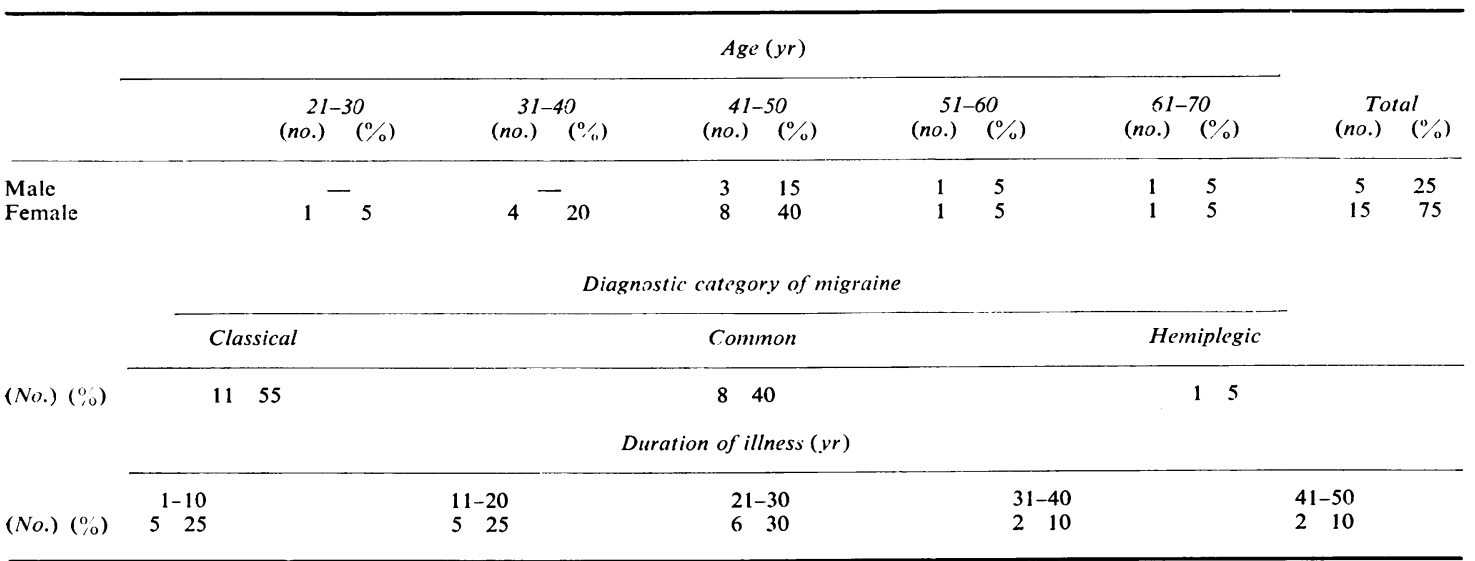


TABLE 5

SIDE-EFFECTS

\begin{tabular}{lcc}
\hline & \multicolumn{2}{c}{ In subjects taking: } \\
Principal symptom or sign & Amitriptyline & Placebo \\
\hline Dry mouth* & 2 & 1 \\
Drowsiness* & 5 & 3 \\
Constipation & 1 & 2 \\
Weight gain & 1 & 2 \\
Nausea & 2 & 3 \\
Increased headaches $\dagger$ & 1 & 1 \\
Depression & 1 & 1 \\
Hypertension & 1 & - \\
Disturbing dreams & 1 & 7 \\
Dizziness & 1 & 20 \\
No side-effects & 4 & \\
\hline Total & 20 & \\
\hline
\end{tabular}

* Five subjects on amitriptyline and one subject on placebo also complained of dry mouth and nausea in addition to the principal side-effect.

† One patient withdrawn from trial because of increased headaches on placebo.

TABLE 6

DOSAGE ESTABLISHED DURING LAST 23 WEEKS OF TREATMENT

\begin{tabular}{|c|c|c|c|c|c|}
\hline \multicolumn{6}{|c|}{ Amitriptyline (mg) } \\
\hline $\begin{array}{c}10 \\
\text { (no.) }\end{array}$ & $\begin{array}{c}20 \\
\text { (no.) }\end{array}$ & $\begin{array}{c}30 \\
\text { (no.) }\end{array}$ & $\begin{array}{c}40 \\
\text { (no.) }\end{array}$ & $\begin{array}{c}50 \\
\text { (no.) }\end{array}$ & $\begin{array}{c}60 \\
(n o .)\end{array}$ \\
\hline 2 & 3 & 7 & 1 & 2 & 5 \\
\hline \multicolumn{6}{|c|}{ Placebo (tabs.) } \\
\hline - & 2 & 3 & 4 & 5 & 6 \\
\hline 1 & - & 1 & 3 & - & 15 \\
\hline
\end{tabular}

Average dose of amitriptyline $30-40 \mathrm{mg}$.

TABLE 7

EFFECT OF AMITRIPTYLINE ON FREQUENCY OF ATTACKS

\begin{tabular}{|c|c|c|c|c|c|}
\hline \multirow{3}{*}{$\begin{array}{l}\text { Increase } \\
(\text { no. })(\%)\end{array}$} & \multicolumn{5}{|c|}{ Effect on attacks of individual subjects } \\
\hline & \multicolumn{5}{|c|}{$\%$ Reduction } \\
\hline & $\begin{array}{c}0-29 \% \\
(\text { no. })(\%)\end{array}$ & $\begin{array}{c}30-49 \% \\
\text { (no.) }(\%)\end{array}$ & $\begin{array}{c}50-69 \% \\
(\text { no. })(\%)\end{array}$ & $\begin{array}{l}70-100 \% \\
(\text { no. })(\%)\end{array}$ & $\begin{array}{c}\text { Total } \\
(\text { no. })(\%)\end{array}$ \\
\hline $4 \quad 20$ & 315 & 420 & 420 & $5 \quad 25$ & $20 \quad 100$ \\
\hline \multicolumn{6}{|c|}{ Effect on total attacks (no.) } \\
\hline \multicolumn{2}{|c|}{ Amitriptyline } & \multicolumn{2}{|c|}{ Placebo } & \multicolumn{2}{|c|}{ Total } \\
\hline \multicolumn{2}{|c|}{207} & \multicolumn{2}{|c|}{356} & \multicolumn{2}{|c|}{563} \\
\hline
\end{tabular}

\pm Reduction on amitriptyline $=42 \% \quad(P<0.001)$.

The significance of the differences was not altered when two patients with more than 80 attacks over the period of the trial were excluded. taking amitriptyline than when taking placebo $(\mathrm{P}<0 \cdot 01)$. The number of attacks was reduced by more than $50 \%$ in about half of the subjects, and by more than $70 \%$ in a quarter of them. Four patients had increased frequency of attacks varying from 5 to $47 \%$.

Total attacks were reduced from 356 on placebo to 207 on amitriptyline, a reduction of $42 \%(\mathrm{P}<0.001)$ (Table 7$)$.

Attacks were classified as having no warning, a warning of less than six hours, and a warning of more than six hours. The proportion of attacks in each of these categories was not significantly changed by amitriptyline therapy. There was, however, a difference of the effect of amitripty- is line, which caused a significant decrease for $\overrightarrow{0}$ attacks with no warning or a short warning, and no significant improvement for attacks with a warning of longer than six hours (Table 8).

\section{TABLE 8} TABLE 8
EFFECT ON ATTACKS WITH DIFFERENT DURATION OF
WARNING

\begin{tabular}{|c|c|c|c|c|c|}
\hline $\begin{array}{c}\text { Warning } \\
\text { (hr.) }\end{array}$ & Placebo & Amitriptyline & Total & $\begin{array}{c}\text { \% Improve- } \\
\text { ment } \\
\pm\end{array}$ & $\begin{array}{r}\text { Signifi } \\
\text { cance } \\
\text { 응 }\end{array}$ \\
\hline None & 104 & 63 & 167 & 39 & $\mathrm{P}<0.01$ \\
\hline$<6$ & 226 & 119 & 345 & 47 & $P<0.001$ \\
\hline$>6$ & 26 & 25 & 51 & 4 & NS \\
\hline Total & 356 & 207 & 563 & & \\
\hline
\end{tabular}

Attacks with a duration of less than 24 hours showed a significant decrease with amitriptyline, $\frac{0}{3}$ though this was not better than the average effect of the drug on all attacks. The drug had no significant effect, however, on attacks of longer duration (Table 9).

Both with placebo and amitriptyline, attacks were most frequent in the early morning, declining progressively towards the evening. The drug produced the greatest percentage reduction for those attacks which occurred in the late evening (Table 10).

Where the severity of the attacks was concerned, there was a significant decrease in attacks of for each degree of severity, but the effect was not $N$ different from the average effect of the drug for $\underset{\mathcal{E}}{ }$ 
TABLE 9

EFFECT ON ATTACKS OF DIFFERENT DURATION

\begin{tabular}{cccl}
\hline Duration $(\mathrm{hr})$ & Amitriptyline & Placebo & \\
\hline 24 & 167 & 309 & $\mathbf{P}<0.001$ \\
$>24$ & 40 & 47 & NS \\
\hline Total & 207 & 356 & \\
\hline
\end{tabular}

TABLE 10

EFFECT ON ATTACKS OCCURRING AT DIFFERENT TIMES OF DAY

\begin{tabular}{lcccc}
\hline Time $(\mathrm{hr})$ & Placebo & Amitriptyline & $\begin{array}{c}\% \\
\text { Improvement }\end{array}$ & Significance \\
\hline $00.01-08.00$ & 153 & 87 & 43 & $\mathrm{P}<0.001$ \\
$08.01-12.00$ & 83 & 50 & 40 & $\mathrm{P}<0.05$ \\
$12.01-18.00$ & 62 & 40 & 35 & $\mathrm{P}<0.05$ \\
$18.01-24.00$ & 58 & 30 & 48 & $\mathrm{P}<0.01$ \\
\hline Total & 356 & 207 & & \\
\end{tabular}

TABLE 11

EFFECT OF AMITRIPTYLINE ON ATTACKS OF DIFFERENT SEVERITY

\begin{tabular}{lccccc}
\hline \multicolumn{1}{c}{ Degree } & Placebo & $\begin{array}{c}\text { Amitripty- } \\
\text { line }\end{array}$ & Total & $\begin{array}{c}\% \\
\text { Improvement }\end{array}$ & $\begin{array}{c}\text { Signifi- } \\
\text { cance }\end{array}$ \\
\hline Mild & 105 & 58 & 163 & 45 & $\mathbf{P}<0.001$ \\
Moderate & 133 & 83 & 216 & 38 & $\mathrm{P}<0.001$ \\
Severe & 118 & 66 & 184 & 44 & $\mathrm{P}<0.001$ \\
\hline Total & 356 & 207 & 563 & 42 & $\mathrm{P}<0.001$ \\
\hline
\end{tabular}

all attacks. Amitriptyline thus reduced the number of attacks irrespective of degree (Table 11).

Classifying attacks according to the three reported associated features of depression, nausea, and photophobia, the drug was found to produce a smaller proportion of attacks with associated depression than did the placebo. The decrease was not, however, quite significant at the $5 \%$ level (Table 12). The drug did not have any selective effect on attacks associated with nausea and photophobia.

Subjects were asked to try to identify any precipitating cause of each attack. The reported
TABLE 12

EFFECT OF AMITRIPTYLINE ON ASSOCIATED FEATURES OF ATTACKS

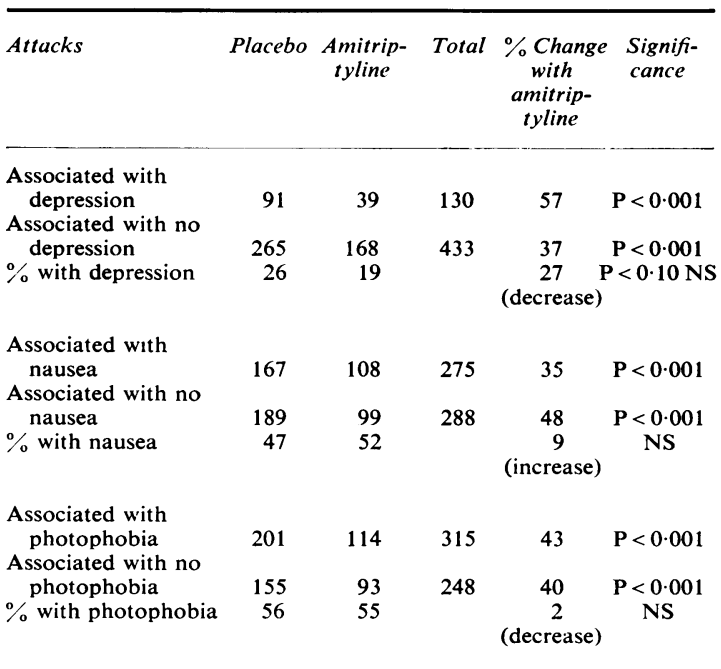

causes were classified into six categories: no specific cause, weather, psychological stress, food or drink, menstruation, and fatigue.

Amitriptyline had its greatest effect on attacks with no specific cause, the reduction being twofold. For attacks recognized as due to other causes, the reduction with amitriptyline was not significant and was least for those attacks attributed to fatigue (Table 13).

When attacks during the period on placebo were compared with those during the control period of equal duration, a slight increase of attacks by 11 subjects when on placebo was shown, which did not reach a significant level.

TABLE 13

EFFECT ON ATTACKS WITH DIFFERENT CAUSE

\begin{tabular}{lccc}
\hline Cause & Placebo & Amitriptyline & Significance \\
\hline No specific cause & 218 & 104 & P $<0.01$ \\
Weather & 14 & 6 & NS \\
Psychological stress & 36 & 24 & NS \\
Food or drink & 8 & 6 & NS \\
Menstrual period & 19 & 14 & NS \\
Fatigue & 61 & 53 & NS \\
\hline Total & 356 & 207 & \\
& & & \\
\hline
\end{tabular}


There was, however, a reduction of duration, there being a significantly greater percentage of attacks recorded of shorter duration during the placebo period. There was a similar reduction in severity of attacks, in that when treated with placebo subjects experienced a lower percentage of severe attacks and a correspondingly higher percentage of mild or moderate attacks but the difference was significant only at the $10 \%$ level. The placebo significantly reduced attacks due to psychological stress, though attacks with no specific cause were significantly increased, as were those occurring in the early morning. There were no significant differences for other classifications (Table 14).

TABLE 14

EFFECT OF PLACEBO ON ATTACKS WHEN COMPARED WITH ATTACKS DURING CONTROL PERIOD

\begin{tabular}{|c|c|c|c|c|}
\hline & Placebo & Control & Total & Significance* \\
\hline Total attacks & 356 & 316 & 672 & NS \\
\hline Attacks $<24 \mathrm{hr}$ duration & 309 & 253 & $562\}$ & $P<0.05 t$ \\
\hline Attacks $>24 \mathrm{hr}$ duration & 47 & 63 & $110\}$ & $P<0.05 \dagger$ \\
\hline Mild or moderate & 238 & 191 & 429) & $P<0.10+$ \\
\hline Severe & 118 & 125 & $243\}$ & $P<0.10 \dagger$ \\
\hline $\begin{array}{l}\text { Attacks with no specific } \\
\text { cause }\end{array}$ & 218 & 169 & 387 & $P<0.05$ \\
\hline $\begin{array}{l}\text { Attacks due to } \\
\text { psychological stress }\end{array}$ & 36 & 66 & 102 & $\mathrm{P}<0.01$ \\
\hline $\begin{array}{l}\text { Attacks occurring betwee } \\
00.01-08.00 \\
08.01-12.00 \\
12.01-18.00 \\
18.01-24.00\end{array}$ & $\begin{array}{r}153 \\
83 \\
62 \\
58\end{array}$ & $\begin{array}{r}122 \\
106 \\
48 \\
40\end{array}$ & $\begin{array}{r}275 \\
189 \\
110 \\
98\end{array}$ & $\begin{array}{c}P=0.05 \\
P<0.10 \\
N S \\
P<0.10\end{array}$ \\
\hline
\end{tabular}

* Tested for difference from chance.

+ Tested for difference of percentages.

\section{DISCUSSION}

Results indicate a prophylactic effect in reducing the frequency of migraine, comparable with that shown in more recently introduced prophylactic agents. Sjaastad and Stensrud (1971) in a doubleblind study of Catapresan (ST155 clonidine) showed that $62 \%$ of patients improved with the drug, $38 \%$ having a $50 \%$ reduction or more. Wilkinson (1969) in a preliminary trial of this drug showed a $66 \%$ improvement, and Shafar, Tallett, and Knowlson (1972) have more recently shown a reduction in mean frequency of attacks by about one-third at the end of a 12 month follow-up period. Lance, Anthony, and Somerville (1970) found that Pizotifen (BC 105) produced improvement in $50 \%$ of subjects. Arthur and Hornabrook (1971) found that this drug gave a $50 \%$ reduction in headaches in $40 \%$ of their subjects. Dalsgaard-Nielsen (1968) showed improvement in $66 \%$ of cases taking Antaminic Substance (B.P. 400 Sandoz) with $36 \%$ considerably improved.

The method of selecting subjects gave a population well motivated to persist with regular therapy and which suffered slightly less severe migraine than the subjects chosen for some of the above trials. Although the subjects may have had greater psychological problems-and therefore be expected to respond to amitriptylinethere was no clinical evidence of depression, and all the patients continued in their normal occupations throughout the trial.

The method of recording attacks is suitable only for those who are intelligent and well motivated but has advantages over subjectivet estimates of improvement. Two of the subjects who had more attacks on amitriptyline reported that they felt considerably better, which was later not confirmed on their charts. The methot of recording symptoms also allows elimination of headaches which are not migraine attacks of which was noted as a problem by Weissman $\overrightarrow{0}$ (1971). However, it was necessary to disregard $\overrightarrow{ }$ only three headaches of a non-migrainous nature in this study.

Plasma levels of tricyclic drugs have been shown to vary considerably in subjects taking the same dose (Braithwaite, Goulding, Theano, Bailey, and Coppen, 1972). There is also a considerable positive correlation between the plasma level and subjective side-effects (Åsberg, Cronholm, Sjöqvist, and Tuck, 1970). In this present study, variation of dosage was allowed in each subject. The dose finally selected was one which produced no appreciable side-effects. It is very likely that greater improvement in migraine would have resulted if a higher dose had been encouraged in the face of initial sideeffects, which have been shown to diminish after a few weeks of therapy. It may be that a reason for this drug not previously finding favour as a migraine prophylactic is that migraine sufferers are particularly subject to unpleasant side-effects if given the usual recommended starting dose of 
$75 \mathrm{mg}$ daily. The drug appeared to have its maximum effect after several weeks of therapy, indicating the need for the relatively long period on each preparation. In most cases, in the present trial, this could have been due to modifications in dosage occurring at the start of treatment.

No explanation is evident for the selective effect of the drug on attacks of shorter warning and shorter duration. Further research on the action of prophylactic drugs on particular types of attack would be of interest. It is possible that the greater reduction of morning and evening attacks could be related to serum levels of the drug, the maximum dose of which was taken by most patients in the evening. The lack of a selective effect on either mild or severe attacks is in contrast with the findings of Arthur and Hornabrook (1971) with Pizotifen, which exerted its effect particularly on the more severe attacks.

There is a clear distinction between the marked effect of the drug on attacks not due to recognizable cause and those where the cause could be more clearly defined, particularly those associated with fatigue. Migraine is postulated to be a reaction to a variety of causal agents and it is possible that the drug had a mitigating effect on attacks by causal agents which may provoke a less vigorous response. One patient who was completely headache free on the drug reported having slight prodromal symptoms in response to his usual, and for him possibly the most potent, provoking stimuli.

A number of possibilities have been put forward as to the mode of action of prophylactic agents in migraine. Plasma serotonin level has been found to drop sharply at the onset of migraine headache and remain at a low level throughout the attack (Curran, Hinterberger, and Lance, 1965). Serotonin was shown to constrict scalp arteries (Lance, Anthony and Gonski, 1967), and it was postulated that methysergide may act in migrainous subjects by maintaining extracranial vasoconstriction on occasions when plasma serotonin falls (Lance, Anthony, and Somerville, 1970). Tricyclic antidepressants have been shown to increase serotonin levels in the rat brain but only in high dosage (Kivalo, Rinne, and Karinkanta, 1961). It is possible, however, to postulate firstly that the tricyclic drug blocks the uptake of serotonin into various tissues, especi- ally the mast cells, and thereby increases circulating levels.

Other observations, however, suggest that these drugs inhibit the re-uptake from the extracellular space into the nerve ending of constrictor substances such as noradrenaline, which are released as the transmitter substance on nerve stimulation (Glowinski, Axelrod, and Iversen, 1966). A similar effect was shown to take place in peripheral tissues as well as in the brain (Carlsson and Waldeck, 1965). The maintenance of higher levels of such vasoconstrictor substances is another possible mode of action.

Thirdly, amitriptyline may potentiate noradrenergic sympathetic vasoconstriction giving less vasodilation during the migraine attack. Recent work such as that of Alexander and Niño (1969) and Coull, Crooks, DingwallFordyce, Scott, and Weir (1970) on the cardiovascular complications of long-term therapy with psychotropic drugs must be borne in mind.

The only hint of such a problem during the trial were two subjects who suffered from raised blood pressure. The first was a man aged 50 years who had an initially raised blood pressure of $160 / 105 \mathrm{~mm} \mathrm{Hg}$. He had been on amitriptyline therapy for 24 weeks when he complained of dizziness. His blood pressure was found to be $210 / 110 \mathrm{~mm} \mathrm{Hg}$ but it was agreed that he should complete the trial. The other subject was a 44 year old lady who had no initial hypertension but complained of depression and increased headaches a week after the change from amitriptyline to placebo. Her blood pressure was found to be $150 / 100 \mathrm{~mm} \mathrm{Hg}$ and again it was agreed that the trial should continue. The role of amitriptyline in the occurrence of the hypertension is uncertain. In both cases the blood pressure reverted to initial levels with conservative measures though in neither case was amitriptyline continued beyond the time necessary for completion of the trial. In all other cases there was no change in blood pressure.

The range of prophylactic agents used in migraine is increasing Amitriptyline as a wellknown drug for the treatment of depression may, in lower dosage, be useful for migraine sufferers who respond unsatisfactorily to other preparations. Decisions about therapy in a particular patient must obviously take into consideration the severity of the migraine, response to other 
drugs, and the unknown long-term effects of newer prophylactic agents, many of which are related in structure to the tricyclic antidepressants.

We wish to thank Dr. Gordon Hems for his assistance and Drs. J. F. F. Rooney and A. M. C. Duffus of the Clinical Research Department, Roche Products Ltd., for advice and supplying the amitriptyline (Laroxyl) and placebo. We acknowledge with gratitude the persistence of those who recorded attacks during the 18 month trial, and thank Miss Kathleen Morrison and Miss Helen Ramsay for preparing and typing the script.

\section{REFERENCES}

Ad Hoc Committee on Classification of Headache (1962). Journal of the American Medical Association, 179, 717-718.

Alexander, C. S., and Niño, A. (1969). Cardiovascular complications in young patients taking psychotropic drugs. A preliminary report. American Heart Journal, 78, 757-769.

Åsberg, M., Cronholm, B., Sjöqvist, F., and Tuck, D. (1970). Correlation of subjective side effects with plasma concentrations of nortriptyline. British Medical Journal, 4, 18-21.

Arthur, G. P., and Hornabrook, R. W. (1971). The treatment of migraine with BC 105 (Pizotifen): a double blind trial. New Zealand Medical Journal, 73, 5-9.

Braithwaite, R. A., Goulding, R., Theano, G., Bailey, J., and Coppen, A. (1972). Plasma concentration of amitriptyline and clinical response. Lancet, 1, 1297-1300.

Carlsson, A., and Waldeck, B. (1965). Rapid release of ${ }^{3} \mathrm{H}$-metaraminol induced by combined treatment with protriptyline and reserpine. Journal of Pharmacy and Pharmacology, 17, 327-328.
Coull, D. C., Crooks, J., Dingwall-Fordyce, I., Scott, A. M. and Weir, R. D. (1970). Amitriptyline and cardiac disease. Lancet, 2, 590-591.

Curran, D. A., Hinterberger, H., and Lance, J. W. (1967). Methysergide. In Research and Clinical Studies in Headache, Vol. 1, pp. 74-122. Edited by A. P. Friedman. Karger: Basel.

Dalsgaard-Nielson, T. (1968). Therapeutic results of prophylactic treatment for 'classic' migraine with antaminic substance (BP 400 Sandoz). Headache, 8, 6-15.

Friedman, A. P. (1968). The migraine syndrome. Bulletin of the New York Academy of Medicine, 44, 45-62.

Glowinski, J., Axelrod, J., and Iversen, L. L. (1966). Regiona studies of catecholamines in the rat brain. Journal of Pharmacology and Experimental Therapeutics, 153, 30-41.

Kivalo, E., Rinne, U. K., and Karinkanta, H. (1961). The effect of imipramine on the 5-hydroxytryptamine content and monoamine oxidase activity of the rat brain and on the excretion of 5-hydroxyindole acetic acid. Journal of Neurochemistry, 8, 105-108.

Lance, J. W., Anthony, M., and Gonski, A. (1967). Serotonin, the carotid body, and cranial vessels in migraine. Archives of Neurology, 16, 553-558.

Lance, J. W., Anthony, M., and Somerville, B. (1970) Comparative trial of serotonin antagonists in the management of migraine. British Medical Journal, 2, 327-330.

Lance, J. W., and Curran, D. A. (1964). Treatment of chronic tension headache. Lancet, 1, 1236-1239.

Mahloudji, M. (1969). Prevention of migraine. British Medical Journal, 1, 182-183.

Shafar, J., Tallett, E. R., and Knowlson, P. A. (1972). Evalua tion of clonidine in prophylaxis of migraine. Lancet, $1 \stackrel{+}{\oplus}$ 403-407.

Sjaastad, O., and Stensrud, P. (1971). 2-(2, 6-Dichlorophenyl的 amino)-2-imidazoline hydrochloride (ST 155 or Cata presan) as a prophylactic remedy against migraine. Acre Neurologica Scandinavica, 47, 120-122.

Weissman, L. (1971). Experimental design in headache treato ment. Headache, 10, 166-171.

Wilkinson, M. (1969). Clonidine for migraine. Lancet, 430. 